https:// doi.org/10.18485/iipe_cpti.2020.ch5

\title{
ODGOVOR KINE NA NOVI BEZBEDNOSNI IZAZOV
}

\begin{abstract}
Ivona LAĐEVAC
Apstrakt: Poslednje decenije XX veka bile su vrlo turbulentne i uzrokovale su velike promene $\mathrm{u}$ međunarodnim odnosima. U značajnoj meri promenjen odnos snaga između vodećih država sveta odrazio se na međunarodnu bezbednost. Promene su postale još drastičnije prelaskom u XXI vek. I dok ih je najveći broj država sveta dočekao nespreman, Narodna Republika Kina (NR Kina) se izdvojila sposobnošću da na njih odgovori na način koji joj je obezbedio rastuću ulogu u međunarodnim odnosima.

Ključne reči: međunarodni odnosi, međunarodna bezbednost, Narodna Republika Kina, strateško partnerstvo, Ruska Federacija
\end{abstract}

\section{Uvodne napomene}

Kraj XX veka obeležio je krah međunarodnog poretka uspostavljenog završetkom II svetskog rata. Posledica tog kraha bila je suočavanje sveta sa procesom pregrupisavanja snaga u posthladnoratovskim međunarodnim odnosima, dok je ishod pregrupisavanja bilo stvaranje formalno multipolarnog sveta $\mathrm{u}$ kojem se isticala dominacija jedne države Sjedinjenih Američkih Država (SAD). Na taj način je započeo period Pax Americana, koji jedan broj teoretičara međunarodne politike označava i vremenom hegemonije SAD.

Svoj dominantan položaj SAD su utvrđivale bilo angažovanjem sopstvenih vojnih kapaciteta, bilo kroz akcije NATO koji je, opet pod

${ }^{1}$ Autorka je naučni saradnik u Institutu za međunarodnu politiku i privredu, Beograd, e-mail: ivona@diplomacy.bg.ac.rs

Rad je nastao u okviru projekta „Srbija i izazovi u međunarodnim odnosima 2020. godine", koji finansira Ministarstvo prosvete, nauke i tehnološkog razvoja Republike Srbije, a realizuje Institut za međunarodnu politiku i privredu tokom 2020. godine. 
njihovim presudnim uticajem, u poslednje dve i po decenije znatno proširio ne samo članstvo, već i sferu uticaja. Granice tog vojno-političkog saveza značajno su pomerene ka Rusiji, premda su toj državi neposredno pre ujedinjenja dve Nemačke data obećanja da se, u zamenu za njeno neprotivljenje tom činu, „NATO neće širiti na istok “. ${ }^{2}$ Međutim, protokom vremena pojavile su se tvrdnje, i one su sve češće, da takvih obećanja nikada nije ni bilo, da je reč o pogrešnim tumačenjima izjava zvaničnika SAD, odnosno da, u krajnjoj liniji, potpisani dokument takve sadržine ne postoji. ${ }^{3}$

Apsolutna dominacija jedne države, ili makar utisak da takva dominacija postoji, u međunarodnim odnosima dovodi do transformacije odnosa snaga koja, kao takva, predstavlja izazov ostalim državama. U takvim okolnostima date države, najpre, menjaju svoju spoljnopolitičku strategiju, a potom se, ukoliko već same ne mogu da dostignu takmaca, opredeljuju i za saveze sa sebi sličnim državama kako bi osujetile aktuelnog hegemona.

U savremenim međunarodnim odnosima tu hipotezu potvrđuje spoljnopolitička strategija Narodne Republike Kine (NR Kine), očigledno uzrokovana "nezadovoljstvom svetskim poretkom predvođenim Amerikom". ${ }^{4}$

U tom kontekstu ne bi bilo preterano reći da je u toku razvoj novog vida politike zaprečavanja (containment policy) Džordža Kenana (George Kennan). ${ }^{5}$ Nesporno je da je ograničavanje jačanja uticaja Amerike, i to ne samo na

${ }^{2}$ Mark Kramer, The Myth of a No-NATO-Enlargement Pledge to Russia, The Washington Quarterly, April 2009, 32:2, DOI: 10.1080/01636600902773248, Center for Strategic and International Studies, Washington, Internet, http://dialogue europe.org/uploads/File/resources/TWQ\%20 article\%20on\%20Germany \%20and \%20NATO.pdf. 08/08/2020.

${ }^{3}$ Videti: Mary Elise Sarotte, "A Broken Promise? What the West Really Told Moscow About NATO Expansion", Foreign Affairs, September/October 2014, http:/ / www. foreignaffairs.com/articles/141845/mary-elise-sarotte/a-broken-promise, 20/08/2020; Mark Kramer, The Myth of a No-NATO-Enlargement Pledge to Russia, op. cit.; Bill Bradley, "A Diplomatic Mystery", Foreign Policy, August 22, 2009, http://foreignpolicy.com/2009/08/22/a-diplomatic-mystery; Michael Rühle, "NATO enlargement and Russia: myths and realities", NATO Review Magazine, http:/ / www.nato.int/docu/review/2014/Russia-Ukraine-Nato-crisis/Natoenlargement-Russia/EN/index.htm, 20/12/2017.

${ }^{4}$ Paul Bolt, "Sino-Russian Relations in a Changing World Order", Strategic Studies Quarterly, Winter 2014, p. 49.

${ }^{5}$ Videti: John Lewis Gaddis, Strategies of Containment: A Critical Appraisal of American National Security Policy during the Cold War, Oxford University Press, New York, 1982. 
prostoru Evroazije već i u globalnim okvirima, u interesu NR Kine. Tako definisan interes suprotan je interesima SAD za koje je još Zbignjev Bžežinski (Zbigniew Brzezinski), u svojoj „Velikoj šahovskoj tabli“, rekao da imaju „imperativ da spreče pojavu izazivača na području Evroazije, izazivača sposobnog da dominira njome, a time istovremeno sposobnog da predstavlja pretnju Americi“" ${ }^{6}$

Zbog svega navedenog, pitanje bezbednosti postaje centralno pitanje međunarodnih odnosa na kraju XX i početku XXI veka.

\section{Savremeni izazovi međunarodne bezbednosti}

Pitanje savremenih izazova međunarodne bezbednosti je prioritetno za sve aktere $\mathrm{u}$ međunarodnoj politici. Činjenica je da postoje brojni bezbednosni izazovi, rizici i pretnje na koje države pojedinačno ne mogu adekvatno da odgovore i zbog kojih je neophodan jedinstven odgovor međunarodne zajednice. Sem toga, otvoreno je i pitanje odnosa snaga između „velikih igrača“ u međunarodnim odnosima.

Jedan od ključnih faktora za oblikovanje struktura svetskog političkog sistema je ravnoteža snaga. Ravnoteža snaga u međunarodnim odnosima proističe iz teorije strukturalnog realizma i podrazumeva da se slabije države, akteri sa manjim potencijalom moći, okupljaju jer su u takvom okruženju cenjenije i sigurnije, i tako objedinjuju svoje defanzivne snage zarad odvraćanja jače strane od napada. ${ }^{7}$

Pri tome, međunarodna bezbednost se određuje kao stanje nepostojanja pretnji u sistemu međunarodnih odnosa. Ovo je izvedena definicija, koja se oslanja na jedno od klasičnih tumačenja pojma bezbednosti. ${ }^{8}$ Bezbednost se najčešće određuje kao stanje nepostojanja pretnji, odnosno ugrožavanja usvojenih vrednosti. Tako gledano, pojam bezbednosti je veoma široko definisan, pa je stoga i pojam međunarodne bezbednosti široko definisan. Na prvi pogled, čini se da nije moguće utvrditi ko je subjekat međunarodne

6 "... it is imperative that no Eurasian challenger emerges, capable of dominating Eurasia and thus of also challenging America." Zbigniew Brzezinski, The Great Chess Board: American primacy and Its Geostrategic Imperatives, Basic Books, A Member of the Perseus Book Group, New York, 1997, p. 15.

${ }^{7}$ Kenneth Waltz, Theory of International Politcs, Addison-Wesley Pub. Co, 1979, pp. 125-126.

${ }^{8}$ Radoslav Gaćinović, Uvod u studije bezbednosti, Draslar partner, Beograd, 2007, str. 6. 
bezbednosti, koji su izazovi, a koje pretnje. Suština i jeste u tome da se subjekti, izazovi i pretnje bezbednosti različito definišu u zavisnosti od promena u međunarodnim odnosima. ${ }^{9}$ Od vremena kada su države bile jedini subjekti na međunarodnoj sceni, a izazovima i pretnjama bezbednosti se smatralo samo ono što direktno ugrožava državni interes, došlo se do toga da se danas subjektima međunarodnih odnosa smatra širok spektar aktera - od međunarodnih organizacija, pa do pojedinaca - a izazovi i pretnje bezbednosti su sve ono što može ugroziti bilo koga od njih.

Uprkos brojnim prognozama, pobeda Zapadnog bloka u Hladnom ratu nije dovela i do dugoročnog održavanja jednopolarne strukture svetskog političkog sistema sa Zapadom kao jedinim polom (koncepcija “The West and the Rest" $).{ }^{10}$ Uzdizanje NR Kine i Ruske Federacije, kao i njihovo multilateralno organizovanje (Brazil, Rusija, Indija, Kina i Južnoafrička Republika - BRIKS, Šangajska organizacija za saradnju i sl.) pokazalo je težnju da se napravi balans snaga u svetskom političkom sistemu. Želja NR Kine i RF da i one budu nosioci političkih impulsa, ekonomskih aktivnosti i razvojnih programa na globalnom nivou, utiče na to da se struktura svetskog političkog sistema menja, da ove zemlje igraju sve značajniju ulogu u međunarodnim odnosima i više se pitaju o stvarima koje se tiču međunarodne bezbednosti. ${ }^{11}$

Promene u međunarodnim odnosima, novi pokretački procesi i pravci razvoja, nisu samo subjektivan doživljaj država članica međunarodne zajednice, već objektivna činjenica priznata i u sistemu Organizacije ujedinjenih nacija. Iako se ovoj organizaciji, s pravom, često prigovara da ne uspeva da svoje delovanje prilagodi promenjenim okolnostima, pod njenim okriljem je bilo pokušaja utvđivanja izazova sa kojima su akteri međunarodnih odnosa suočeni.

Tako je na zasedanju Generalne skupštine Ujedinjenih nacija, krajem 2004. godine, tadašnji Generalni sekretar Kofi Anan (Koffi Annan), predstavio dokument kojim je ukazao na činjenicu da se svet nalazi na raskršću, te da je

${ }^{9}$ Filip Ejdus, Međunarodna bezbednost: teorije, sektori, nivoi, BCBP, Beograd, 2012, str. 68.

${ }^{10}$ Aleksandar Dugin, Geopolitika postmoderne - doba novih imperija: osvrti na geopolitiku XXI veka, Prevodilačka radionica Rosić, Beograd, Nikola Pašić, Beograd, Srpski sabor Dveri, Beograd, 2009, str. 26-27.

${ }^{11}$ Robert D. Kaplan, The Revenge of Geography: What the Map Tells Us About Coming Conflicts and the Battle Against Fate, Random House Trade Paperbacks New York, 2012. 
neophodno postići konsenzus u vezi sa pretnjama i izazovima sa kojima se svetska organizacija, ali i njene članice pojedinačno, svakodnevno sreću. Uz posebno isticanje razlika u karakteristikama međunarodnih odnosa 1945. godine i međunarodnih odnosa 2004. godine, pomenutim dokumentom je sumirano šest kategorija pretnji sa kojima je svet danas suočen:

1. Pretnje ekonomske i socijalne prirode, koje uključuju siromaštvo, zarazne bolesti i uništavanje prirode;

2. Međudržavni sukobi;

3. Unutrašnji konflikti, uključujući građanske ratove, genocid i druge oblike teških krivičnih prekršaja;

4. Nuklearno, radiološko, hemijsko i biološko oružje;

5. Terorizam, i

6. Transnacionalni organizovani kriminal. ${ }^{12}$

Pored ovih novih ili netradicionalnih izazova, bez obzira na globalizaciju kao fenomen koji briše granice, države se i dalje suočavaju sa tradicionalnim, realističkim, izazovima, pitanjima jačanja i očuvanja moći što pokazuje da teritorija, kao jedna od osnovnih kategorija realizma, baš kao ni politička geografija, nije izgubila na značaju.

\section{Saradnja sa Ruskom Federacijom kao odgovor na bezbednosni izazov}

\section{Bilateralna saradnja}

Međunarodni odnosi obiluju primerima raznorodnih okolnosti i faktora koji su uticali na države da se, umesto odnosa konfrontacije, opredele za odnose savezništava i/ili partnerstava. U pozadini takvih opredeljenja uvek je stajao interes očuvanja teritorije i stanovništva, a onda i, u onoj meri u kojoj je to bilo moguće, političke stabilnosti. Ipak, savremeni međunarodni odnosi, pod uticajem globalizacije i njome uzrokovane rastuće međuzavisnosti, razlikuju se i po tome što se države, ali i njihovo stanovništvo, suočavaju sa novim izazovima i pretnjama na koje nije uvek lako naći odgovor. Upravo

12 "Executive Summary - A more secure world: Our shared responsibility“, Report of the High-level Panel on Threats, Challenges and Change", United Nations, 2004, https:/ / www.un.org/en/events/pastevents/pdfs/secure_world_exec_summary.pdf 08/08/2020. 
ti novi izazovi i načini njihovog prevazilaženja pokazuju koliki je značaj partnerskih odnosa.

Jedan od takvih primera je strateško partnerstvo između Rusije i Kine, čijim su uspostavljanjem obe države predupredile mnoge potencijalne izazove, rizike i pretnje.

Razvoj događaja u poslednjoj deceniji XX veka, dramatično urušavanje istočnog bloka, promene na političkoj karti Evrope i ubrzano jačanje SAD, predstavljali su razlog više za približavanje Kine i Rusije.

Dve susedne države su, izuzev ekonomskih, imale i zajedničke geopolitičke i bezbednosne interese. I mada su se obe i po pojedinačnim geografskim, ekonomskim i vojnim pokazateljima, kao i po političkom značaju, mogle ubrojiti u vodeće zemlje sveta, kod obe je postojala svest da bi ih partnerski odnos mogao učiniti daleko snažnijim. Sem toga, delile su iste stavove $u$ vezi sa reformama međunarodnih političkih i finansijskih institucija, ali i sa potrebom očuvanja i poštovanja principa međunarodnog prava, koji se odnose na teritorijalni integritet i suverenitet, drugim rečima povratkom u okvire vestfalskog poretka.

Sve navedeno ušlo je $u$ temelje strateškog partnerstva između ove dve zemlje. Najpre je 1992. godine, prilikom posete Kini tadašnjeg ruskog predsednika Borisa Nikolajeviča Jeljcina (Борис Николаевич Ельцин), doneta zajednička izjava o prijateljskim odnosima, da bi 1994. godine, tokom uzvratne posete Moskvi kineskog predsednika Đanga Cemina (Jiang Zemin), oba predsednika izjavila da su uspostavili „konstruktivne partnerske odnose orijentisane ka 21. veku" ("constructive partnership relations oriented toward the 21st century"). Prilikom nove posete Jeljcina Kini, aprila 1996, međusobni odnosi su podignuti na nivo "strateških, odnosa saradnje, partnerstva..." ("strategic, cooperative, partnership relations...").

Naredne, 1997. godine, na samitu u Moskvi dvojica predsednika objavila su „Zajedničku deklaraciju o multipolarnom svetu i stvaranju novog međunarodnog poretka" (Российско-китайская совместная декларация о многополярном мире и формировании нового международного порядка). Očekivano, Deklaracija je sa naročito velikom pažnjom propraćena u SAD, pošto je, po mišljenju mnogih, predstavljala direktan izazov njihovom položaju hegemona u posthladnoratovskom dobu. ${ }^{13}$ Ovo protivljenje

${ }^{13}$ Videti: Bobo Lo, “The Long Sunset of Strategic Partnership_Russia's Evolving China Policy“, International Affairs, Vol. 80, No. 2, Israeli-Palestinian Conflict (Mar., 2004), 
hegemonizmu je naišlo na otpor, pa su se mogla čuti i mišljenja da je reč o indirektnoj konfrontaciji sa SAD i NATO.${ }^{14}$ Nema sumnje da su takvu reakciju izazvali delovi deklaracije u kojima Rusija i Kina objavljuju da će „u duhu partnerskih odnosa, raditi na promovisanju multipolarnog sveta i uspostavljanju novog svetskog poretka" ${ }^{15}$

Taj poredak bi se, po njihovoj zamisli, morao zasnivati na odnosima razumevanja i uzajamnog poštovanja svih zemalja, jednakosti, dijaloga i saradnje, dok bi hegemonizam, politika moći, konfrontacija i sukobi bili isključeni. Istovremeno, nije prihvatliiva ni podela država na „velike i male, jake i slabe, bogate i siromašne", budući da su sve one ravnopravne članice međunarodne zajednice. U tom duhu, nijedna država nema pravo da, koristeći politku sile, nameće sebe kao hegemona, niti da monopolizuje svetski poredak. ${ }^{16}$

Zbog svega navedenog, neophodno je jačanje uloge Ujedinjenih nacija, njenih organa, $u$ prvom redu Saveta bezbednosti, kao i striktno poštovanje Povelje kako bi se očuvali svetski mir i bezbednost. Izgradnja mirnog, stabilnog, pravednog i racionalnog međunarodnog političkog i ekonomskog poretka je nužna i imperativ je istorijskog razvoja. Uz ocenu da je čovečanstvo na pragu novog doba, dve države pozvale su sve ostale da, putem otvorenog dijaloga, zajedno oblikuju novi, stabilan i pravedan poredak. ${ }^{17}$

Negativne reakcije na Zapadu su, $u$ suštini, samo potvrdile da je deklaracija Rusije i Kine odgovor na stvarno stanje u međunarodnim odnosima. Pokazalo se da bezbednosni koncept za koji se zalažu SAD nije izašao iz hladnoratovskih okvira, te da NATO i dalje ima nameru da pomera svoje granice i jača vojne kapacitete. Sa stanovišta Rusije i Kine to je „tendencija koja može da ugrozi bezbednost pojedinačnih zemalja, ali i da stvori tenzije u regionalnim i međunarodnim okvirima. ${ }^{\text {"18 }}$

Blackwell Publishing on the behalf of the Royal Institute of International Affairs, pp. 295-309, http://www.scribd.com/doc/44764020/The-Long-Sunset-of-StrategicPartnership-Russia-s-Evolving-China-Policy, 08/08/2020.

${ }^{14}$ Stroupe W. Joseph, "Russia And China 'Cooking Something Up" ", Asia Times 10-1-6, Internet, http:/ / www.rense.com/general73/cook.htm. 09/08/2020.

15 „Российско-Китайская совместная декларация о многополярном мире и формировании нового международного порядка“, http:/ docs.cntd.ru/document /190215509/08/2020.

${ }^{16}$ Ibid.

${ }^{17}$ Ibid.

${ }^{18}$ Российско-Китайская совместная декларация о многополярном мире и формировании нового международного порядка, op. cit. 
Nasuprot pozivu Rusije i Kine da "putem otvorenog dijaloga, zajedno oblikuju novi, stabilan i pravedan poredak", SAD su bile odlučne da "testiraju“ ostatak sveta nekada samostalno, a nekada korišćenjem snaga NATO. ${ }^{19}$ Tako su od 1991. do 2001. godine izvele čak pet vojnih intervencija: u Kuvajtu, Somaliji, Haitiju, Bosni i Hercegovini i SR Jugoslaviji. Od svih navedenih, najkontroverznija je bila odluka o sprovođenju vazdušnih napada na teritoriju SRJ, zbog navodnog kršenja ljudskih prava albanske manjine na Kosovu i Metohiji. Saglasno međunarodnom pravu i sistemu međunarodnih odnosa utemeljenom i opšteprihvaćenom $u X X$ veku, intervencija ove vrste je morala biti odobrena od strane Saveta bezbednosti nakon konstatovanja povrede Glave VII Povelje OUN. Međutim, takvo odobrenje nikada nije dato. $S$ druge strane, niti SAD niti članice NATO nisu pretrpele nikakve sankcije zbog te akcije, čime je samo potvrđen dominantan status SAD. ${ }^{20}$

Kina i Rusija su se sve vreme protivile upotrebi sile i vazdušnim napadima na teritoriju SRJ, pozivajući se na, od osnivanja sistema Ujedinjenih nacija, opšteprihvaćene principe poštovanja međunarodnog prava, principe nemešanja $u$ unutrašnje poslove država i poštovanja teritorijalnog suvereniteta i integriteta. Međutim, s obzirom na činjenicu da su SAD zaobišle svetsku organizaciju, uticaj ove dve zemlje je, u najmanju ruku, marginalizovan. S druge strane, takvo ponašanje SAD je samo ubrzalo približavanje Rusije i Kine u nastojanju da osujete njihovu želju za globalnom dominacijom. Obe zemlje nastoje da smanje američko prisustvo makar u onim regionima koje pripadaju njihovim tradicionalnim interesnim sferama. Iako se ponekada i njihove interesne sfere poklapaju, Amerika, sama po sebi, predstavlja izazov sa kojim se, bar u ovom trenutku, lakše suočiti zajednički nego pojedinačno. Ispoljenom arogancijom, propagiranjem stava da je "Amerika jedina spremna i pozvana da uređuje svet, jer ima moć, najuzvišenije vrednosti i osoben osećaj za međunarodnu odgovornost,

${ }^{19}$ Videti: Miroslav Glišić, Dejan Stojković, Ivona Lađevac, “NATO Crisis Management Concept: Twenty Years After Bombing of The Federal Republic of Yugoslavia", in: Nebojša Vuković (ed.), David vs. Goliath: NATO war against Yugoslavia and its implications, Institute of International Politics and Economics, Faculty of Security Studies of Belgrade University, Belgrade, 2019, pp. 327-349.

${ }^{20}$ Videti: Dušan Proroković, Ivona Lađevac, "Kosovo case and the role of the United Nations", in: Dušan Proroković (ed.), Kosovo: sui generis or precedent in international relations, Institute of International Politics and Economics, Belgrade, 2018, pp. 170-183. 
odnosno sposobnost „, da tvori poredak“, ${ }^{21}$ samo učvršćuje odluku RF i NRK da adekvatno odgovore na taj izazov.

"Adekvatan odgovor" predstavljala je njihova odluka da najpre proklamuju, a potom i formalno ozvaniče strateško partnerstvo za XXI vek potpisivanjem „Ugovora o dobrosusedstvu, prijateljstvu i saradnji“ (Договор о добрососедстве, дружбе и сотрудничестве между Российской Федерацией и Китайской Народной Республикой) 16. jula 2001. godine. ${ }^{22}$ Zaključen je na period od 20 godina, uz mogućnost automatskog produženja za narednih pet.

U periodu koji je usledio, na osnovama Ugovora o dobrosusedstvu, prijateljstvu i saradnji, odnosi između dve zemlje dostigli su izuzetno visok nivo. Najbolja ilustracija ove tvrdnje je činjenica da su na desetogodišnjicu njegovog potpisivanja, predstavnici obe zemlje izjavili da se međusobno smatraju "glavnim i najvažnijim strateškim i kooperativnim partnerom" ("each other's principal and most important strategic, cooperative partners") ${ }^{23} \mathrm{O}$ visokom stepenu saradnje govori i činjenica o velikom broju potpisanih dodatnih ugovora kojima su regulisana pitanja ekonomske razmene, energetske saradnje, kao i trgovine naoružanjem.

Ekonomska i trgovinska saradnja važe za jednu od najznačajnih oblasti saradnje budući da njihova realizacija doprinosi napretku i razvoju svake zemlje. S druge strane, reč je o oblasti u kojoj se dogovori najlakše mogu postići zbog uvek prisutnog interesa i mogućnosti za sticanje višestrukih dobiti. Kada je reč o Rusiji i Kini i njihovom razvoju odnosa u ovoj sferi, on

${ }^{21}$ Miroslav Mladenović, Jelena Ponomareva, „Kina-Amerika-Rusija - globalni trougao 21. veka“, Sociološki pregled, Srpsko sociološko društvo, Beograd, vol. 45, br. 4, str. 473.

22 Договор о добрососедстве, дружбе и сотрудничестве между Российской Федерацией и Китайской Народной Республикой, 17 июля 2001 г. в “РГ" Федеральный выпуск №2746, Internet, http:/ / www.rg.ru/2009/03/20/russiakitai-dok.html, 20/12/2017. Za Rusku Federaciju potpisnik je bio Vladimir Vladimirovič Putin, a za Narodnu Republiku Kinu Đang Cemin. Ugovor je stupio na snagu sedam godina kasnije, nakon što su obe zemlje ratifikovale akcione planove za njegovu primenu.

${ }^{23}$ Jingiie Li, "Sino-Russian Strategic Partnership Cooperative Relations and the US Factor", The ASAN Forum, Online ISSN 2288-5757, November-December 2014, Vol. 2, No. 6, http:/ / www.theasanforum.org/sino-russian-strategic-partnership-cooperativerelations-and-the-us factor/p. 2. 10/08/2020. 
se postepeno pokrenuo tokom devedesetih godina prošlog veka, a sa Sporazumom o strateškom partnerstvu počeo da se ubrzava.

Po dostupnim podacima, prvi značajan skok u obimu trgovinske razmene između Rusije i Kine dogodio se 2011. godine, kada je došlo do uvećanja od skoro 14 puta (od 5,72 milijarde dolara na 79,3 milijarde) u odnosu na devedesete. ${ }^{24} \mathrm{Na}$ polju investicija takođe je zabeležen rast, i to sa 100 miliona dolara kineskih investicija u Rusiji na 2,6 milijardi, dok su ruske u Kini porasle sa 220 miliona na skoro milijardu dolara. ${ }^{25}$ Važno je napomenuti, da je izbijanje svetske finansijske krize 2009. godine imalo negativan uticaj, te neminovno dovelo do pada obima trgovinske razmene. Tako je u 2009. godini došlo do pada od 31,8 odsto u odnosu na prethodnu, 2008. godinu. ${ }^{26}$

Kada je reč o strukturi robe, Kina je u Rusiju izvozila uglavnom poljoprivredne proizvode, mašine i opremu, dok su okosnicu ruskog izvoza u Kinu činili energenti, bilo kao sirovine, bilo kao gotovi proizvodi.

I u periodu posle 2015. godine, trgovinska razmena između Rusije i Kine nastavila je trend konstantnog rasta i to po stopi od oko 20 odsto godišnje. U 2016. obim razmene je bio 69,5 milijardi dolara, dok je u 2017. godini dostigao 84,07 milijardi. Naredne dve godine trebalo je da dovedu do rasta na čak 200 milijardi dolara u 2020. godini, međutim, taj rast je izostao zbog izbijanja pandemije korona virusa (COVID-19) početkom 2020. ${ }^{27}$

Kada je reč o kineskom izvozu u Rusiju, njegova godišnja stopa rasta je oko 14,8 odsto, i u 2017. godini iznosio je 42,88 milijardi dolara. S druge strane, uvoz robe iz Rusije je uvećan za oko 28 odsto, odnosno premašio je 40 milijardi. $^{28}$

24 "General Administration of Customs People's Republic of China", China Customs Statistic Details, http:/ / english.customs.gov.cn/newsroom/statisticsdetail/4728765b001b-4a5b-b3cf-3c904bd387 82, 02/02/2018.

25 "China in Focus: Lessons and Challenges 2012", OECD, http://www.oecd.org/ china/50011051.pdf, 02/02/2018.

26 "General Administration of Customs People's Republic of China", China Customs Statistic Details, op. cit.

27 "Russia's Trade With China Up 22\%", The Moscow Times, Oct. 17 2017, https:// themoscowtimes.com/articles/russias-trade-with-china-up-22-to-59285, 22/02/2018.

28 "Russia-China trade volume exceeds expectations, hitting $\$ 84 \mathrm{bn}$ ", RT, published time: 12 Jan, 2018 10:49, https:/ / www.rt.com/business/415692-russia-china-tradeturnover/, 22/01/2018. 
Postignutim rezultatima zadovoljni su politički vrhovi obe zemlje. Tako je prilikom posete Pekingu, novembra 2017. godine, ruski predsednik, Vladimir Putin (Владимир Путин), izrazio zadovoljstvo „vidljivim rezultatima“ koji „,...odražavaju nivo dostignutog strateškog partnerstva“ ${ }^{29}$ Međutim, uzimajući u obzir da se saradnja i dalje može unapređivati, kao i pronalaziti novi modaliteti, podsetio je da su u maju 2017. Rusija i Kina osnovale zajednički fond od 68 milijardi juana (preko 10 milijardi dolara) namenjen daljem razvoju trgovine, investicija i naučne saradnje. Važno je naglasiti da obe zemlje favorizuju uvođenje novih preferencijalnih aranžmana kako bi se povećala upotreba rublje i juana u međusobnim transakcijama.

Do sada plasirane investicije su uglavnom vezane za velike infrastrukturne projekte, među kojima prednjače ulaganja u izgradnju gasovoda i postrojenja za preradu sirovih energenata. Primeri takvih investicionih projekata su izgradnja sibirskog gasovoda i postrojenje na poluostrvu Jamal, na ruskom Arktiku.

Sibirski gasovod, Snaga Sibira, dužine $3.000 \mathrm{~km}$ je "Gaspromova" investicija vrednosti 55 milijardi dolara. To je prvi gasovod koji je povezao direktno Rusiju i Kinu, najvećeg svetskog proizvođača gasa i najvećeg svetskog potrošača, i koji je počeo sa radom 2. decembra 2019. godine. Ova investicija je deo ugovora o 30-godišnjem snabdevanju Kine ruskim gasom u količini od preko 1,15tn kubnih metara gasa i vrednosti od 400 milijardi dolara. ${ }^{30}$ Planirana je i izgradnja drugog kraka gasovoda koji će ići do Mongolije i Kazahstana kako bi se mogao koristiti i za transport gasa $u$ zemlje Evrope, ali i druge delove Kine, odnosno unutrašnju Kinu i njene zapadne provincije.

Izuzev ovog projekta, značajan je i projekat izgradnje gasnog postrojenja na poluostrvu Jamal, koji predstavlja najveći zajednički ekonomski projekat Rusije i Kine pokrenut 8. decembra 2017. godine. ${ }^{31}$ Iz ovog postrojenja, ukupnog kapaciteta od 5,5 miliona tona godišnje, sa bogatog ruskog

\footnotetext{
${ }^{29}$ Ibidem

30 "Power of Siberia", Gazprom, https://www.gazprom.com/projects/power-ofsiberia/, 11/08/2020.

31 "Yamal, Largest China-Russia Cooperative Project, Now Supplies China With Arctic LNG", Yicai global, https:// www.yicaiglobal.com/news/yamal-largest-china-russiacooperative-project-now-supplies-china-arctic-lng, 22/01/2018.
} 
Arktika, Kina će se na godišnjem nivou snabdevati sa četiri miliona tona tečnog gasa. ${ }^{32}$

Projekat je značajan još i zato što predstavlja prvi završeni prekomorski projekat nakon pokretanja inicijative Pojas i put, odnosno njegov polarni krak, ali i zbog toga što će omogućiti Kini značajnije snabdevanje čistim energentima koji će, u krajnjoj liniji, dovesti do sprovođenja jednog od zaključaka 18. Kongresa KP Kine o podizanju kvaliteta životne sredine i izgradnji „lepše Kine“. ${ }^{33}$

Dve zemlje takođe rade i na stvaranju prolaza na Severnom moru, na arktičkoj ruti, kako bi smanjile vreme potrebno za transport robe iz Kine u Evropu. Očekivano, takvi planovi nailaze na protivljenje bivših sovjetskih baltičkih republika i Finske, koje su posvećene realizaciji projekta izgradnje pruge Arktičkog koridora koji bi se protezao od Helsinkija do Kirkenea u arktičkom krugu. ${ }^{34}$

Pogrešno bi bilo zaključiti da se ekonomska saradnja Rusije i Kine odnosi samo na infrastrukturne projekte, trgovinsku razmenu i energente. Obe zemlje rade i na uvođenju novih tehnologija u sve segmente svojih odnosa, pa tako razvijaju 5G tehnologije, ali i razrađuju planove radi pospešivanja internet trgovine ${ }^{35} \mathrm{Za}$ to je naročito zainteresovana Kina, s obzirom na značajan skok životnog standarda i postojanje srednje klase od oko pola milijarde ljudi, uz napomenu da milijardu Kineza ima pristup onlajn trgovini.

To je razlog što obe zemlje angažuju veliki broj IT stručnjaka za rad na razvijanju onlajn platformi koje će biti primenjive i u Evropi, pošto su i Kina i Rusija zainteresovane za učešće na evropskom tržištu.

Uprkos velikom obimu trgovinske razmene, kao i postojanju ekonomske saradnje na visokom nivou, činjenica je da između dve zemlje postoji izvesna neravnoteža. Jedan od uzroka je globalne prirode, budući

\footnotetext{
32 Prema procenama, rezerve tečnog gasa na Jamalu iznose 1,3 triliona kubnih metara. 33 "CPC incorporates 'Beautiful China' into two-stage development plan", Xinhua, http:/ / europe.chinadaily.com.cn/china/2017-10/18/content_33404345.htm, 22/01/2018.

34 "Russia-China Bilateral Trade Up 30\% In Q1 2017", Russia Briefing, Posted on May 4, 2017, https:// www.russia-briefing.com/news/russia-china-bilateral-trade-30-q12017.html/, 22/01/2018.

${ }^{35}$ Ibidem
} 
da je Kina prvi izvoznik sveta a Rusija 16, dok se, kada je o uvozu reč, Kina nalazi na drugom a Rusija na 25. mestu. ${ }^{36}$

Međutim, iako neravnoteža postoji, ona se ne odražava na postojeću ekonomsku saradnju koja je u stalnom usponu i, s obzirom na pokrenute projekte i nagoveštene planove, sve je kompleksnija. Uostalom, tome su doprinele i Evropska unija i SAD koje su sistemom svojih sankcija, figurativno rečeno, "gurnule" Rusiju u kinesko naručje na duži rok.

\section{Saradnja u multilateralnim okvirima}

Izuzev posvećenosti unapređivanju i produbljivanju međusobnih odnosa, za dve zemlje veliki značaj imaju i multilateralni oblici saradnje. lako su obe članice velikog broja organizacija, sa aspekta strateškog partnerstva značajno je nekoliko njih.

\section{Šangajska organizacija za saradnju}

Šangajska organizacija za saradnju je proistekla iz mehanizma „Šangajske petorke“ u koji su se 1996. godine, na inicijativu Rusije i Kine, sem ove dve zemlje uključili Kazahstan, Kirgistan i Tadžikistan. ${ }^{37}$ Osnovni razlog za njihovo okupljanje bila je težnja pet pomenutih država da se verifikuje „saglasnost o učvršćivanju poverenja u vojnoj sferi i o smanjenju oružanih snaga u graničnom pojasu“ ${ }^{38}$

Pet godina kasnije, 15. juna 2001. godine, ovaj mehanizam saradnje postao je prava međunarodna organizacija sa sedištem $u$ Pekingu, a tom

${ }^{36}$ U kineskom izvozu su najzastupljeniji računari, oprema za kablovsku komunikaciju, telefoni, integralna kola i delovi za razne mašine, dok najviše uvozi energente, zlato i rudu gvožđa. Glavni izvozni artikli Rusije su energenti, i to gas i gasni derivati i ugalj. Kada je o uvozu reč, Rusija najviše uvozi lekove, automobile, delove za razne mašine i grejna postrojenja. Videti: https://atlas.media.mit.edu/en/profile/ country/chn/ i https://atlas.media.mit.edu/en/profile/country/rus/.

${ }^{37}$ Šangajska petorka je nastala zbog potrebe demarkacije granica četiri bivše sovjetske republike sa Kinom i, istovremeno, njihove demilitarizacije. Od kada je u Šangaju 1996. godine održan prvi samit predsednika svih pet država postala je praksa da se oni održavaju svake godine.

${ }^{38}$ Miroslav Mladenović, Zoran Kilibarda, „Šangajska organizacija za saradnju“, Vojno delo, proleće 2011, str. 25. 
prilikom je doneta i Deklaracija o osnivanju ŠOS-a. ${ }^{39}$ Postojećim članicima tada se priključio i Uzbekistan.

Na sledećem sastanku šefova država i vlada članica, održanom u Sankt Petersburgu, 7. juna 2002. godine usvojena je i Povelja organizacije. ${ }^{40}$ Usvajanje Povelje označilo je "definisanje ciljeva i principa, područja saradnje, radna tela i način funkcionisanja“" ${ }^{41}$

Među navedenim ciljevima, posebno se ističe jačanje međusobnog poverenja, unapređenje multidisciplinarne saradnje, zajednička borba protiv terorizma, separatizma, različitih oblika ekstremizama i kriminalnih aktivnosti, saradnja u prevenciji konflikata i $\mathrm{dr}^{42}$

Članstvo ŠOS-a, prvi put od osnivanja, prošireno je 2017. godine pristupanjem Indije i Pakistana. ${ }^{43}$ Obe zemlje su, inače, od 2005. godine imale status posmatrača. Ovaj događaj ispraćen je sa velikim interesovanjem s obzirom na oštra neslaganja koja između dve države postoje u vezi sa teritorijom Kašmira još od 1947. godine.

Među posmatračima su ostali Mongolija (2004), ${ }^{44}$ Iran (2005), ${ }^{45}$ Avganistan (2012) ${ }^{46}$ i Belorusija (2015). ${ }^{47}$

39 "Declaration on the Establishment of the Shanghai Cooperation Organization", eng.sectsco.org/load/193054/, 02/04/2018.

40 "Charter of the Shanghai Cooperation Organization", The Shanghai Cooperation Organisation (SCO), eng.sectsco.org/load/203013/ 10/08/2020.

${ }^{41}$ Miroslav Mladenović, Zoran Kilibarda, „Šangajska organizacija za saradnju“, op. cit., str. 26.

42 Ibidem

43 "Accession of India, Pakistan to SCO carries historical significance: SCO leaders", Xinhua, 2017-06-09, http://www.xinhuanet.com/english/2017-06/09/c_136353 604.htm, 10/08/2020.

44 "Mongolia Receives Observer Status IN SCO", Sputnik, 17.06.2004, https:/ / sputnik news.com/onlinenews/2004061739763081/ 10/08/2020.

${ }^{45}$ Farrukh Usmonov, “The Shanghai Cooperation Organization: Russia's View on Iran's Candidacy", Central Asia and the Caucasus, Vol. 15, Issue 3, 2014, https:/ cyber leninka.ru/article/n/the-shanghai-cooperation-organization-russia-s-view-on-irans-candidacy, 10/08/2020.

46 "The Shanghai Cooperation Organisation (SCO) has decided to grant Afghanistan observer status", Pajhwok, 07 June 2012, https://www.pajhwok.com/en/2012/ 06/07/sco-accepts-afghanistan-observer, 20/04/2018.

47 "Belarus becomes observer in Shanghai Cooperation Organization", Belsat, 2015. 07.10, http:/ / belsat.eu/en/news/belarus-becomes-observer-shanghai-cooperationorganization/, 20/04/2018. 
Organizacija pokriva gotovo celu Evroaziju i gotovo polovinu svetske populacije. Države članice imaju velika očekivanja od ove organizacije, a naročito Rusija i Kina. Tako je Vladimir Putin jednom prilikom, neposredno pre održavanja jednog od samita ŠOS-a, rekao da organizacija "gaji duh Śangaja na prostoru za koji zapadni analitičari smatraju da postoji sukob civilizacija i da ona pospešuje saradnju između hrišćansko-pravoslavne, budističke i muslimanske zajednice" ${ }^{48}$

Jačanje vojno-bezbednosne saradnje zemalja okupljenih u ŠOS-u, može se dovesti u vezu sa njihovim protivljenjem dominaciji SAD u svim delovima sveta, pa i na teritoriji Centralne Azije i Evroazije uopšte. Još jedan od razloga za zajedničko nastupanje u ovoj organizaciji je, bez sumnje, dugotrajni građanski rat u Avganistanu i opasnost od prelivanja tog sukoba i širenja fundamentalističkih islamskih ideja. Bojeći se takvih scenarija, vlade zemalja Centralne Azije su intenzivirale saradnju sa svojim moćnim susedima, od kojih su, bez obzira na izraze prijateljstva, donekle i zazirale.

Međutim, vojno-bezbednosna saradnja ni u kom trenutku nije ograničila ove zemlje da šire polja međusobne saradnje, premda su stavovi Rusije i Kine po tom pitanju bili drugačiji. Naime, Kinu su interesi usmerili da posmatra ŠOS kao „perspektivno tržište i izvor sirovina, dok Rusija nastoji da usmeri aktivnost ŠOS u oblasti borbe protiv "tri zla“: terorizam, ekstremizam, separatizam". ${ }^{49}$

I jedna i druga su uspele u svojim nastojanjima. Kina je ekonomsku saradnju između članica podigla na visok nivo, šireći svoje tržište, ali i diverzifikujući izvore energenata. Za članice ŠOS-a efekti te saradnje su poželjni, i one uglavnom posmatraju Kinu kao „motor“ daljeg razvoja.

ŠOS veliku pažnju posvećuje i saradnji u oblasti kulture i to na vrlo visokom nivou. Tako je 2008. godine formiran i Univerzitet ŠOS u čiji je sastav ušlo 53 univerziteta iz zemalja članica. ${ }^{50}$ Očekuje se ispunjenje nekoliko funkcija, poput ,jačanja međusobnog poverenja i dobrosusedskih odnosa; razvoja integrativnih procesa $u$ oblasti obrazovanja, nauke i tehnologije;

48 "The Shanghai Cooperation Organization: Prospects For A Multipolar World", Global research, May 22, 2009, https:// www.globalresearch.ca/the-shanghai-cooperationorganization-prospects-for-a-multipolar-world/13707, 20/04/2018.

${ }^{49}$ Miroslav Mladenović, Zoran Kilibarda, „Šangajska organizacija za saradnju“, op. cit., str. 28.

${ }^{50}$ Op. cit., str. 30 . 
obezbeđivanja novih podsticaja širenju multilateralne obrazovne, naučne i kulturne saradnje; povećanja mogućnosti da mladi steknu kvalitetno moderno obrazovanje i da nastavnici i naučni radnici uspostavljaju naučne kontakte; promovisanja efiksane saradnje zemalja članica u oblasti političke, ekonomske, naučno-tehnološke i kulturne saradnje“ ${ }^{51}$

Što se Rusije tiče, njen uspeh je što je približila ŠOS Organizaciji dogovora (ugovora) o kolektivnoj bezbednosti (ODKB). Naime, u oktobru 2007. godine članice ŠOS-a potpisale su Memorandum o saradnji sa ODKB, organizacijom koja predstavlja klasični vojni savez. ${ }^{52}$ Potpisanim Memorandumom dogovoreno je proširivanje saradnje $u$ oblasti bezbednosti, a $u$ vezi sa pitanjima organizovanog kriminala i krijumčarenja narkotika.

Sem Rusije i Kine i ostale članice ŠOS-a imaju neke svoje interese. Tako, recimo, kroz članstvo u ŠOS-u Uzbekistan i Kazahstan uspevaju da Rusiju drže na pristojnoj udaljenosti, gradeći bliže odnose sa Kinom. Sa svoje strane, Kirgistan i Tadžikistan se trude da i u okviru ove organizacije slede politiku Rusije. A opet, interes Rusije je bio i da se u punopravno članstvo ŠOS-a primi i Indija. Naravno, Kina je na isti način razmišljala zalažući se za prijem Pakistana.

Bez obzira na interese koji se uvek ne poklapaju, kao i različite poglede na pojedina pitanja, ŠOS predstavlja uspešan oblik multilateralne saradnje, forum u kojem se raspravlja o različitim izazovima bezbednosti. Jedan od stalnih oblika saradnje koji kontinuirano sprovode je održavanje zajedničkih antiterorističkih vežbi.

Osnov za održavanje antiterorističkih vežbi predstavlja „Šangajska konvencija o borbi protiv terorizma, separatizma i ekstremizma" (The Shanghai Convention on terrorism, separatism and extemism) doneta 2001. godine. ${ }^{53}$ Značaj ove konvencije je veliki i sa stanovišta međunarodne zajednice u celini, budući da je "ona prva, na međunarodnom planu,

\footnotetext{
${ }^{51}$ Ibidem

${ }^{52}$ Ugovor kojim je osnovana Organizacija (ugovora) dogovora o kolektivnoj bezbednosti (The Collective Security Treaty (CST)), potpisan je 15. maja 1992. godine. Članice ove organizacije postale su Jermenija, Belorusija, Kazahstan, Kirgizija, Ruska Federacija i Tadžikistan. Ugovor je od 1. novembra 1995. registrovan i u OUN.

${ }^{53}$ Navedeno prema: Miroslav Mladenović, Zoran Kilibarda, „Šangajska organizacija za saradnju“", op. cit., str. 29.
} 
definisala separatizam i ekstremizam kao nasilne metode koje predstavljaju krivično delo". ${ }^{4}$

Na osnovama Šangajske konvencije o borbi protiv terorizma, separatizma $i$ ekstremizma je i formirana Regionalna antiteroristička struktura (RATS). Zadaci i funkcije glavnog organa, Izvšnog komiteta, RATS-a su određeni „u tri prioritetna pravca: 1) koordinaciono-operativni pravac (koordinacija i saradnja kompetentnih organa zemalja članica u borbi s terorizmom, ekstremizmom, provođenje antiterorističkih vežbi i dr.; 2) međunarodnopravno usmerenje (učešće $\mathrm{u}$ pripremi međunarodnih dokumenata po pitanjima borbe s terorizmom, uključujući i onu u okviru OUN, saradnja sa Savetom bezbednosti itd.), i 3) informaciono-analitički pravac (formiranje i popunjavanje baze podataka RATS, prikupljanje i analiza informacija po pitanju borbe sa terorizmom i dr.). ${ }^{45}$

Od presudnog značaja za produbljivanje ovog domena saradnje unutar ŠOS-a je ugovor zaključen avgusta 2007. godine, na sedmom samitu, održanom u Biškeku, „Ugovor o dugoročnom dobrosusedstvu, prijateljstvu i saradnji Šangajske organizacije za saradnju“" (Treaty on Long-Term GoodNeighborliness, Friendship and Cooperation Between the Member States of the Shanghai Cooperation Organization). ${ }^{56}$ Ovaj dokument predstavlja prvi multilateralni dokument političke sadržine koji su potpisale države članice. Uporedo sa potpisivanjem ovog dokumenta, održana je i prva antiteroristička vežba u kojoj su učestvovale sve države članice, „Mirovna misija 2007" (Peace Mission 2007). ${ }^{57}$

Važno je istaći, da sve države članice nemaju obavezu da učestvuju u svim vežbama, to zavisi od dogovora, ali je pravilo da je lokacija uvek na teritoriji ŠOS-a.

${ }^{54}$ Ibidem

${ }^{55}$ Miroslav Mladenović, Zoran Kilibarda, „Šangajska organizacija za saradnju“, op. cit., str. 30 .

56 “Treaty on Long-Term Good-Neighborliness, Friendship and Cooperation Between the Member States of the Shanghai Cooperation Organization" in: Key Normative Documents of the Shanghai Cooperation Organization, pp. 173-178, https://www. hrichina.org/sites/default/files/PDFs/Reports/SCO/2011-HRIC-SCO-Whitepaper AppendixA-SCO-Docs.pdf 11/08/2020.

${ }^{57}$ Marcel De Haas, “The ‘Peace Mission 2007' Exercises: The Shanghai Cooperation Organisation Advances", Advanced Research and Assessment Group, September 2007, https://www.clingendael.org/sites/default/files/pdfs/20070900_cscp_paper _haas.pdf $11 / 08 / 2020$ 
Posmatrajući prirodu odnosa Ruske Federacije i Narodne Republike Kine unutar ŠOS-a, preovlađuje utisak da obe države nastoje da, prilagođavajući ih svojim interesima, podjednako jačaju i ekonomsku i bezbednosnu saradnju $\mathrm{u}$ organizaciji.

\section{Organizacija ujedinjenih nacija}

Ruska Federacija i Narodna Republika Kina, zajedno sa Velikom Britanijom i SAD, na konferenciji u Dambarton Ouksu 1944. godine, ${ }^{58}$ započele su rad na dokumentu čijim je usvajanjem naredne godine osnovana Organizacija ujedinjenih nacija. Kao država koja je prva ušla u rat sa silama osovine, Kina je dobila čast da osnivački akt organizacije koja je zamenila nekadašnju Ligu naroda, Povelju Ujedinjenih nacija, prva potpiše.

Međutim, zbog unutrašnjih prilika u Kini i postojanja dve vlade, od kojih je svaka branila svoj legitimitet, Narodna Republika Kina se tek Rezolucijom 2758 Generalne skupštine „vratila“ u Ujedinjene nacije i u Savet bezbednosti koji je do tada, zbog kineskog iznuđenog odsustva, bio prilično disfunkcionalan..$^{59}$

Ruska Federacija i Narodna Republika Kina su kao države osnivači OUN i stalne članice Saveta bezbednosti, po Glavi VII Povelje OUN najznačajnijeg organa ove međunarodne organizacije, čuvara svetskog mira, ostale verne principima na kojima one funkcionišu. U uslovima promenjenog odnosa snaga one i dalje insistiraju na ovim principima, smatrajući ih garancijom suverenosti država članica.

Međutim, promene koje su usledile po završetku Hladnog rata, promenjene prilike unutar samih Ujedinjenih nacija, činjenica da je pod pritiskom Amerike došlo do nametnute potrebe sučeljavanja principa poštovanja suvereniteta i principa zaštite ljudskih prava, učinile su ovu

\footnotetext{
${ }^{58}$ Više o konferenciji u Dambarton Ouksu videti: https://www.doaks.org/research/ library-archives/dumbarton-oaks-archives/historical-records/75th-anniversary/ blog/the-dumbarton-oaks-conversations-1944, 25/04/2018.

${ }^{59}$ Resolution 2758 (XXVI), Restoration of the Lawful Rights of the People's Republic of China in the United Nations, General Assembly, 25 October 1971, https:// documents-dds-ny.un.org/doc/RESOLUTION/GEN/NR0/327/74/IMG/ NR032774.pdf?OpenElement. 11/08/2020.
} 
borbu težom. Brojni su primeri zloupotrebe ljudskih prava radi ostvarenja nekih drugih, prikrivenih interesa i ciljeva. ${ }^{60}$

Paralelno sa promenom okolnosti, dolazi i do promena u ponašanju stalnih članica Saveta bezbednosti, odnosno, pravo na veto kao mehanizam koji im stoji na raspolaganju, počinju da koriste čak i one članice koje mu nisu bile sklone.

Naime, dok je nekadašnji SSSR, danas Ruska Federacija, rekorder po broju uloženih veta, Narodna Republika Kina je na poslednjem mestu.

Kina je svoj prvi veto uložila 1972. godine na predlog prijema Bangladeša u OUN, a sledeća dva tokom devedestih. Jedan se odnosio na situaciju u Centralnoj Americi (1997), a drugi na Bivšu Jugoslovensku Republiku Makedoniju (1999). ${ }^{6}$

Primetno je da su se tokom devedesetih godina prošlog veka Rusija i Kina sa ostalim članicama razmimoilazile na pitanju Savezne Republike Jugoslavije koja se našla na udaru brojnih sankcija trpevši optužbe da snosi krivicu zbog upotrebe sile na teritorijama bivših republika. U najvećem broju slučajeva one su bile uzdržane, nisu glasale, a u tri slučaja iskorišćeno je pravo veta. ${ }^{62}$

U odnosu na ove prostore, najčvršći stav su zauzele $u$ odnosu na situaciju na Kosovu i Metohiji.

Koristeći kanale unutar SB UN, SAD su pokušavale da pridobiju ostale članice ovog tela da odobre upotrebu vojne sile za intervenciju protiv SR Jugoslavije zbog, navodne, humanitarne krize koju trpi stanovništvo albanskog porekla na KiM zbog dejstava srpskih oružanih snaga. Tako je 23. septembra 1998. usvojena Rezolucija 1199 (1998) kojom se pozivaju strane na prekid sukoba. Ipak, pošto su Rusija i Kina bile rezolutno protiv upotrebe sile, intervenciju nije bilo moguće organizovati pod okriljem UN.

${ }^{60}$ Justin Conlon, "Sovereignty vs. Human Rights or Sovereignty and Human Rights?", July 1, 2004, SAGE Journals, http://journals.sagepub.com/doi/abs/10.1177/ 0306396804045516?journalCode $=$ racb. 11/08/2020.

${ }^{61}$ Pregled svih uloženih veta je dostupan na: Veto List, UN Documentation Research Guide, http:/ / research.un.org/en/docs/sc/quick. 11/08/2020.

${ }^{62}$ United Nations Resolutions on the Former Yugoslavia, http://www.aphref.aph. gov.au_house_committee_jfadt_bosnia_bos_app4.pdf. 11/08/2020. 
U odnosu na političku saradnju, kao bitnu komponentu strateškog partnerstva koje su potpisale, uočava se da su, počev od januara 2007. godine, $\mathrm{u}$ čak osam slučajeva ove dve zemlje imale isti stav, odnosno iskoristile su pravo veta ${ }^{63} \mathrm{U}$ pitanju su bile odluke vezane za Mijanmar i Zimbabve (po jedna) i Siriju (6).

Ovakvim glasanjem RF i NRK pokazuju da su čvrsto rešene da odbrane osnivačke principe UN: principe teritorijalnog integriteta, poštovanja suvereniteta, nemešanja $u$ unutrašnje stvari država i pravo legitimno izabrane vlasti da tu vlast i vrši.

U prošlosti je moglo da se dogodi da jedna od ove dve države na glasanju po nekom pitanju bude uzdržana, a da druga uloži pravo veta. Međutim, slučaj izbijanja krize u Siriji pokazao je da dele iste pozicije, te da jedna drugoj pružaju punu podršku. Jedna od rezolucija na koju su obe uložile veto odnosila se na sankcije čije je uvođenje predloženo zbog navodne upotrebe hemijskog oružja od strane vojnih snaga Bašara Al-asada. ${ }^{64}$

Ovako koordinirani nastupi Rusije i Kine svedoče o visokom stepenu dostignutih odnosa saradnje, ali i o postojanju svesti o neophodnosti zajedničke akcije $\mathrm{u}$ Ujedinjenim nacijama kao jednom od dostupnih sredstava za održavanje kontrateže Americi, ali i jedinom sigurnom načinu usmeravanja sveta od unipolarnog ka multipolarnom sistemu.

\section{Zaključne napomene}

Postojeće bliske veze NR Kine i Ruske Federacije uzrokovane su zajedničkom bezbednosnom pretnjom oličenom u hegemonističkoj ulozi SAD. Upravo iz tog razloga, budući razvoj odnosa između Kine i Rusije umnogome će zavisiti od ponašanja i aktivnosti SAD. U slučaju da Amerika sa NATO nastavi da ,"pritiska” Rusiju, a Kinu politikom rebalansiranja u Aziji i Pacifiku, nema sumnje da će se učvrstiti veze između Rusije i Kine i na bilateralnom i na multilateralnom nivou. U tom slučaju, ne bi trebalo da iznenadi ukoliko dve zemlje odluče da saradnju u oblasti ekonomije i

\footnotetext{
${ }^{63}$ Veto List, UN Documentation Research Guide, op. cit.

${ }^{64}$ Rusija i Kina uložile veto na rezoluciju o sankcijama Siriji, N1, 28.02.2017 http:/ / rs.n1info.com/a231490/Svet/Svet/Rusija-i-Kina-ulozile-veto-na-rezolucijuo-sankcijama-Siriji.html, 11/08/2020.
} 
bezbednosti obogate saradnjom koja ima za cilj unapređenje njihovih vojnih sposobnosti.

\section{Bibliografija}

Brzezinski, Zbigniew, The Great Chess Board: American primacy and Its Geostrategic Imperatives, Basic Books, A Member of the Perseus Book Group, New York, 1997.

Dugin, Aleksandar, Geopolitika postmoderne - doba novih imperija: osvrti na geopolitiku XXI veka, Prevodilačka radionica Rosić, Beograd, Nikola Pašić, Beograd, Srpski sabor Dveri, Beograd, 2009.

Ejdus, Filip, Međunarodna bezbednost: teorije, sektori, nivoi, BCBP, Beograd, 2012.

Gaddis, Lewis John, Strategies of Containment: A Critical Appraisal of American National Security Policy during the Cold War, Oxford University Press, New York, 1982.

Gaćinović, Radoslav, Uvod u studije bezbednosti, Draslar partner, Beograd, 2007.

Glišić, Miroslav, Stojković, Dejan, Lađevac, Ivona, “NATO Crisis Management Concept: Twenty Years After Bombing of The Federal Republic of Yugoslavia", in: Nebojša Vuković (ed.), David vs. Goliath: NATO war against Yugoslavia and its implications Institute of International Politics and Economics, Faculty of Security Studies o Belgrade University, Belgrade, 2019, pp. 327-349.

Jović-Lazić, Ana, Odnosi između Evropske unije i Ruske Federacije - kraj XX $i$ početak XXI veka, Institut za međunarodnu politiku i privredu, Beograd, 2015.

Kaplan, Robert D., The Revenge of Geography: What the Map Tells Us About Coming Conflicts and the Battle Against Fate, Random House Trade Paperbacks New York, 2012.

Mladenović, Miroslav, Ponomareva, Jelena, „Kina-Amerika-Rusija globalni trougao 21. veka“", Sociološki pregled, Srpsko sociološko društvo, Beograd, vol. 45, br. 4, str. 459-476.

Mladenović, Miroslav, Kilibarda, Zoran, „Šangajska organizacija za saradnju“, Vojno delo, proleće 2011, str. 40-58. 
Proroković, Dušan, Lađevac, Ivona, "Kosovo case and the role of the United Nations", in: Dušan Proroković (ed.), Kosovo: sui generis or precedent in international relations, Institute of International Politics and Economics, Belgrade, 2018, pp. 170-186.

Waltz, Kenneth, Theory of International Politcs, Addison-Wesley Pub. Co, 1979.

\section{Dokumenti}

"Charter of the Shanghai Cooperation Organization", The Shanghai Cooperation Organisation (SCO), eng.sectsco.org/load/203013/.

Договор о добрососедстве, дружбе и сотрудничестве между Российской Федерацией и Китайской Народной Республикой, 17 июля 2001 г. в “РГ" - Федеральный выпуск №2746, http:/ / www.rg. ru/2009/03/20/russia-kitai-dok.html 20/12/2017.

"Executive Summary - A more secure world: Our shared responsibility", Report of the High-level Panel on Threats, Challenges and Change", United Nations, 2004, https://www.un.org/en/events/pastevents/ pdfs/secure_world_exec_summary.pdf 08/08/2020.

"General Administration of Customs People's Republic of China", China Customs Statistic Details, http:/ /english.customs.gov.cn/newsroom/ statisticsdetail/4728765b-001b-4a5b-b3cf-3c904bd387 82 02/02/2018.

"Partnership and Co-operation Agreement between Russian Federation and the European Union", 24 June 1994, European Commission, http:/ / europa.eu/rapid/press-release_IP-95-533_en.htm

Resolution 2758 (XXVI), Restoration of the Lawful Rights of the People's Republic of China in the United Nations, General Assembly, 25 October 1971, https:/ / documents-dds-ny.un.org/doc/RESOLUTION/ GEN/NR0/327/74/IMG/NR032774.pdf?OpenElement 11/08/2020.

Российско-Китайская Совместная Декларация о Многополярном Мире и Формировании Нового Международного Порядка, http:// docs.cntd.ru/document/1902155 09/08/2020.

"Treaty on Long-Term Good-Neighborliness, Friendship and Cooperation Between the Member States of the Shanghai Cooperation Organization", in: Key Normative Documents of the Shanghai Cooperation Organization, pp. 173-178, https:/ / www.hrichina.org/sites/default/files/PDFs/Reports 
/SCO/2011-HRIC-SCO-WhitepaperAppendixA-SCO-Docs.pdf $11 / 08 / 2020$.

United Nations Resolutions on the Former Yugoslavia, http:/ / www.aphref. aph.gov.au_house_committee_jfadt_bosnia_bos_app4.pdf. 11/08/2020. Veto List, UN Documentation Research Guide, http:/ / research.un.org/ en/docs/sc/quick. 11/08/2020.

\section{Izvori sa Interneta}

"Accession of India, Pakistan to SCO carries historical significance: SCO leaders", Xinhua, 2017-06-09, http://www.xinhuanet.com/english/ 2017-06/09/c_136353604.htm 10/08/2020.

"Belarus becomes observer in Shanghai Cooperation Organization", Belsat, 2015.07.10, http:// belsat.eu/en/news/belarus-becomes-observershanghai-cooperation-organization 20/04/2018.

Borko, Yuri, "Rethinking Russia-EU Relations", Russia in Global Affairs, No.

3, Moscow, 2004, https://eng.globalaffairs.ru/articles/rethinkingrussia-eu-relations/.

Bradley, Bill, "A Diplomatic Mystery", Foreign Policy, August 22, 2009, http:/ / foreignpolicy.com/2009/08/22/a-diplomatic-mystery

"China in Focus: Lessons and Challenges 2012", OECD, http:// www.oecd. org/china/ 50011051.pdf 02/02/2018.

Conlon, Justin, "Sovereignty vs. Human Rights or Sovereignty and Human Rights?", July 1, 2004, SAGE Journals, http://journals.sagepub.com/ doi/abs/10.1177/0306396804045516?journalCode =racb. 11/08/2020.

"CPC incorporates 'Beautiful China' into two-stage development plan", Xinhua, http:/ / europe.chinadaily.com.cn/china/2017-10/18/content_3 3404345.htm 22/01/2018.

De Haas, Marcel, “The 'Peace Mission 2007' Exercises: The Shanghai Cooperation Organisation Advances", Advanced Research and Assessment Group, September 2007, https://www.clingendael.org/sites/default/ files/pdfs/20070900_cscp_paper_haas.pdf 11/08/2020.

Joseph, Stroupe W., "Russia And China 'Cooking Something Up'", Asia Times 10-1-6, Internet, http://www.rense.com/general73/cook.htm 09/08/2020. 
Kramer, Mark, "The Myth of a No-NATO-Enlargement Pledge to Russia", The Washington Quarterly, April 2009, 32:2, DOI: 10.1080/01636600 902773248, Center for Strategic and International Studies, Washington, Internet, http://dialogueeurope.org/uploads/File/resources/TWQ $\% 20$ article\%20on\%20Germany\%20and\%20NATO.pdf 08/08/2020.

Li, Jingjie, "Sino-Russian Strategic Partnership Cooperative Relations and the US Factor", The ASAN Forum, Online ISSN 2288-5757, NovemberDecember 2014, Vol. 2, No. 6, Internet, http:/ / www.theasanforum.org/ sino-russian-strategic-partnership-cooperative-relations-and-the-us factor 10/08/2020.

Lo, Bobo, “The Long Sunset of Strategic Partnership_Russia's Evolving China Policy", International Affairs, Vol. 80, No. 2, Israeli-Palestinian Conflict (Mar., 2004), Blackwell Publishing on the behalf of the Royal Institute of International Affairs, pp. 295-309, Internet, http:// www.scribd.com/doc/44764020/The-Long-Sunset-of-StrategicPartnership-Russia-s-Evolving-China-Policy. 08/08/2020.

“Mongolia Receives Observer Status IN SCO”, Sputnik, 17.06.2004, https:/ / sputniknews.com/onlinenews/2004061739763081/ 10/08/2020.

"Power of Siberia", Gazprom, https://www.gazprom.com/projects/ power-of-siberia/ 11/08/2020.

Rühle, Michael, "NATO enlargement and Russia: myths and realities", NATO Review Magazine, Internet, http:/ / www.nato.int/docu/review/ 2014/Russia-Ukraine-Nato-crisis/Nato-enlargement-Russia/EN/ index.htm 20/12/2017.

“Russia-China Bilateral Trade Up 30\% In Q1 2017”, Russia Briefing, Posted on May 4, 2017, https:/ / www.russia-briefing.com/news/russia-chinabilateral-trade-30-q1-2017.html/ 22/01/2018

"Russia-China trade volume exceeds expectations, hitting \$84bn", RT, published time: 12 Jan, 2018 10:49, https://www.rt.com/business/ 415692-russia-china-trade-turnover 22/01/2018.

"Russia's Trade With China Up 22\%", The Moscow Times, Oct. 17 2017, https://themoscowtimes.com/articles/russias-trade-with-china-up-22to-59285 22/02/2018.

„Rusija i Kina uložile veto na rezoluciju o sankcijama Siriji“ , N1, 28.02.2017 http:/ / rs.n1info.com/a231490/Svet/Svet/Rusija-i-Kina-ulozile-vetona-rezoluciju-o-sankcijama-Siriji.html 11/08/2020. 
Sarotte, Mary Elise, “A Broken Promise? What the West Really Told Moscow About NATO Expansion", Foreign Affairs, September/October 2014 Issue, Internet, http:/ / www.foreign affairs.com/articles/141845/ mary-elise-sarotte/a-broken-promise 08/08/2020.

"The Shanghai Cooperation Organisation (SCO) has decided to grant Afghanistan observer status", Pajhwok, 07 June 2012, https:/ /www. pajhwok.com/en/2012/06/07/ sco-accepts-afghanistan-observer 20/04/2018.

"The Shanghai Cooperation Organization: Prospects For A Multipolar World", Global research, May 22, 2009, https:/ / www.global research.ca /the-shanghai-cooperation-organization-prospects-for-a-multipolarworld/13707 20/04/2018.

Usmonov, Farrukh, “The Shanghai Cooperation Organization: Russia's View on Iran's Candidacy", Central Asia and the Caucasus, Vol. 15, Issue 3, 2014, https://cyberleninka.ru/article/n/the-shanghai-cooperation organization-russia-s-view-on-iran-s-candidacy. 10/08/2020.

"Yamal, Largest China-Russia Cooperative Project, Now Supplies China With Arctic LNG", Yicai global, https://www.yicaiglobal.com/news/ yamal-largest-china-russia-cooperative-project-now-supplies-chinaarctic-lng 22/01/2018. 


\section{CHINA'S RESPONSE TO THE NEW SECURITY CHALLENGE}

\section{Ivona LAĐEVAC}

Abstract: The last decades of the 20th century were very turbulent and caused great changes in international relations. The significantly changed balance of power between the world's leading countries has affected international security. In the 21st century, changes have become even more drastic. And while most of the countries of the world welcomed them unprepared, the People's Republic of China (PRC) stood out with its ability to respond to them in a way that provided it with a growing role in international relations. China's response was mainly provoked by the dissatisfaction with the American-led world order and unilateralism as the predominant action. In order to overcome such circumstances, China decides to put all its strengths into boosting not only the bilateral but the multilateral cooperation as well. The most prominent examples of those types of cooperation are the cooperation with the Russian Federation, the United Nations Organization, and the Shanghai Cooperation Organization.

Keywords: international relations, international security, the People's Republic of China, strategic partnership, the Russian Federation. 